УДК 577.3+612.82

\author{
Є. А. Уланова, О. О. Шугуров, Н. П. Боцьва, О. В. Сліна \\ Дніпропетровський національний університет ім. Олеся Гончара
}

\title{
ВПЛИВ ФУНКЦІОНАЛЬНОГО СТАНУ М'ЯЗОВОЇ СИСТЕМИ ПАЛЬЦВ РУКИ ЛЮДИНИ НА ДИНАМІКУ ЇХ РУХОВОЇ АКТИВНОСТІ
}

Охарактеризовано закономірності динаміки рухової активності II-V пальців верхніх кінцівок людини. Кількісно оцінено частотно-динамічні характеристики механограм відповідних м'язів залежно від зміни їх функціонального стану. Виявлено якісно подібну динаміку показників під впливом зовнішніх (робота контрлатеральних м'язів) і внутрішніх (стомлення, порушення кровопостачання) факторів. За умови використання подразнення $n$. medianus та n. ulnaris із силою, не меншою за дві реобази, та тривалістю подразнювального імпульсу не менше 4 мс при навантаженні на палець 2040 г забезпечусться максимум середньої потужності, що розвивасться м'язовою системою пальців.

\author{
Е. А. Уланова, О. А. Шугуров, Н. П. Боцьва, Е. В. Елина
}

Днепропетровский национальный университет им. Олеся Гончара

\section{ВЛИЯНИЕ ФУНКЦИОНАЛЬНОГО СОСТОЯНИЯ МЫШЕЧНОЙ СИСТЕМЫ ПАЛЬЦЕВ РУКИ ЧЕЛОВЕКА НА ДИНАМИКУ ИХ ДВИГАТЕЛЬНОЙ АКТИВНОСТИ}

\begin{abstract}
Охарактеризованы закономерности динамики двигательной активности II-V пальцев верхних конечностей человека. Количественно оценены частотно-динамические характеристики механограмм соответствующих мышц в зависимости от изменения их функционального состояния. Выявлена качественно схожая динамика показателей при воздействии внешних (работа контрлатеральных мышц) и внутренних (утомление, нарушение кровоснабжения) факторов. При условии раздражения $n$. medianus и $\boldsymbol{n}$. ulnaris с силой не менее двух реобаз и длительностью раздражающего импульса не менее 4 мс, при нагрузке на палец 20-40 г обеспечивается максимум средней мощности, развиваемой мышечной системой пальцев.
\end{abstract}

\author{
Y. A. Ulanova, O. O. Shugurov, N. P. Botsva, O. V. Yelina \\ Oles' Honchar Dnipropetrovsk National University
}

\section{EFFECT OF MUSCULAR SYSTEM FUNCTIONAL STATE ON HUMAN ARM FINGERS BENDING}

Basic features of the motion activity dynamics of II-V fingers of human superior limbs are analyzed. The frequency-force dependence of arm fingers bending at change of the functional state of their muscular system is quantitatively estimated. Qualitative similarity in dynamics of changes of mechanography features under the influence of external (work of contralateral muscles) and internal (fatigue, blood supply disturbance) factors is determined. Mean power of finger muscular system is maximal when $n$. medianus and n. ulnaris are stimulated with force not less then two rheobases and stimuli width are not less then 4 ms with finger applied weight of $20-40 \mathrm{~g}$. 


\section{Вступ}

Останнім часом рухова активність людини все частіше стає об'єктом дослідження. Фізична працездатність людини аналізується за допомогою таких непрямих показників як максимальне споживання кисню, частота серцевих скорочень та інші $[1 ; 7 ; 12 ; 13]$. Однак параметри працездатності окремих м'язових систем, зокрема пальців руки людини, неможливо оцінити за допомогою таких показників, оскільки вони не пов'язані з обчислюванням механічної роботи, яку відносять до прямих показників фізичної працездатності.

Із погляду фізіології, велике значення для аналізу м'язової працездатності мають регуляторні механізми керування руховими функціями $[2 ; 3 ; 9-11 ; 15 ; 16 ; 18-21]$. При цьому питання проявів рухової активності під час зміни функціонального стану біологічної системи залишається недостатньо дослідженим.

При дослідженні працездатності м'язів людини потрібно оцінювати їх динамічні характеристики, пов'язані 3 механічною роботою. Такими показниками $є$ амплітуда реакції відповіді на зовнішнє подразнення та потужність, що розвивається при цьому м'язовою системою [5; 14]. Більшість досліджень, присвячених питанню м'язової працездатності, проведено на тваринах $[3 ; 4 ; 6 ; 7 ; 11 ; 22]$ або на нижніх кінцівках людини [9; 17]. На даний час недостатньо досліджені показники м'язової працездатності пальців руки людини, хоча саме кисть у більшості професій, наприклад, пов'язаних 3 операторською діяльністю, є головним робочим інструментом. Не з'ясовано залежність рухових і динамічних характеристик пальців від частоти повторюваних простих рухів (згинання пальця та окремих його суглобів). Недостатньо вивчено вплив на частотні характеристики руху пальців різноманітних факторів, які змінюють їх працездатність: навантаження, м'язової втоми, зміни кровообігу працюючих м'язів. Проведення аналізу зазначених характеристик допоможе з'ясувати вплив зміни функціонального стану на працездатність м’язів пальців руки людини.

\section{Матеріал і методи досліджень}

Реєстрацію та аналіз динамічних характеристик руху пальців руки проводили на 68 неврологічно здорових чоловіках і жінках віком 20-47 років в умовах, коли вони не виконували усвідомлених вольових актів, за допомогою спеціалізованого апаратнопрограмного комплексу з комп'ютерною обробкою даних.

При реєстрації механограм руку випробуваного закріплювали у блоці, який фіксував кисть, ліктьову частину, а також усі пальці, крім працюючого. На ділянку працюючого пальця одягали петлю. Жорстку нитку, зв'язану з петлею, у середній частині прикріплювали до верхнього кінця легкого вертикального стрижня та далі перекидали через блок. На кінці нитки закріплювали вантаж, маса якого змінювалась від 10 до 75 г із кроком 5 г. Легкий вертикальний стрижень обертався навколо горизонтальної осі, кут нахилу визначали переміщенням нитки. Нижній кінець стрижня був зв'язаний із феромагнітним осердям, розташованим усередині котушки контуру вимірювального автогенератора. Згинання пальця викликало переміщення осердя та зміни частоти автогенератора. Електричний сигнал від автогенератора йшов на частотний детектор, 3 якого сигнал, що відповідав механограмі, надходив до аналогоцифрового перетворювача, а далі - на ЕОМ із наступним накопиченням і протоколюванням. У процесі експериментів необхідне перетворення цифрових даних відбувалося програмно. Активний подразнювальний електрод накладали залежно від експерименту на рухові точки передпліччя. Анод розташовували на лікті з протилежного боку від катода. Із виходу стимулятора ЕСУ-2 на електрод подавали подразнювальні стимули 134 
силою 200-650 мкА, тривалістю 1-4 мс, домагаючись згинання відповідного пальця. Після цього реєстрували механограму згинання пальців кінцівки.

У ряді дослідів вивчали вплив на працездатність м'язової системи таких додаткових умов як утома м'язів-згиначів, викликана ритмічним стисканням гумової груші пальцями досліджуваної руки з подальшим активним та пасивним відпочинком; навантаження іншої кінцівки шляхом виконання механічної роботи; зміна кровопостачання працюючих м'язів-згиначів пальців шляхом пневматичного впливу при накладанні манжети на плечову артерію.

\section{Результати та їх обговорення}

За результатами серії експериментів, у яких силу подразнювальних імпульсів залишали постійною, але змінювали їх тривалість (від 0,2 до 10 мс з інтервалом 0,05 i 0,10 мс) встановлено, що за тривалості 1 мс реєструється однофазна відповідь. При збільшенні тривалості імпульсу до 2 мс з'являвся, крім зазначеної відповіді, більш ранній пік. При подальшому збільшенні тривалості імпульсу до 4 мс і більше пік, що з'явився першим, але з великим латентним періодом, практично приглушується, і залишається відповідь із меншим латентним періодом. Для виключення участі ЦНС у цих процесах тобто посилення умови автономності - варто збільшити тривалість подразнення до величини 4 мс і більше, що зроблено у подальших дослідах.

При вивченні амплітудно-частотних характеристик згинання пальців руки людини 3 тривалістю подразнювального стимулу 4 мс та силою стимуляції 1,8 порога встановлено, що зі збільшенням частоти стимуляції амплітуда механограм (АМГ) збільшується, досягає максимуму при частоті, відповідній максимальному куту згинання проксимального міжфалангового суглоба, після чого зменшується. Для зручності порівняння АМГ розраховували у відсотках від максимуму кривої для навантаження 10 г. Зі збільшенням навантаження на палець амплітуди механограм зменшуються, а їх максимуми зміщуються у бік низьких частот. При цьому залежність максимальної амплітуди механограми від навантаження на палець близька до лінійної (множинний коефіцієнт кореляції $R^{2}=0,972$ ).

Найбільша амплітуда характерна для середнього пальця (рис. 1), більш низька для вказівного та підмізинного пальців, найменша - для мізинця. При цьому відбувається зміщення максимумів кривих (від середнього до мізинця) в область нижчих частот. На основі збігу усереднених залежностей амплітуд механограм від частоти стимуляції показано рівноцінність функціональних можливостей при виконанні рухів ведучими кінцівками (тобто ліва рука ліворуких і права рука праворуких).

Результати розрахунків показують, що для м'язової системи пальців потужність практично постійна в межах точності експерименту ( 30 мВт). Середня потужність, що розвивається досліджуваним пальцем, - робота, виконувана пальцем при піднятті вантажу за одиницю часу. Але оптимальна частота, що відповідає максимуму амплітуди механограми, не буде збігатися з частотою, за якої є максимальною середня потужність біосистеми. Виконувана пальцем робота суттєво залежить від величини навантаження, прикладеного до пальця. Виконувана робота за одиницю часу значно більша при середніх навантаженнях (20-50 г), ніж при низьких (10-15 г) і високих (60-75 г). Положення максимумів потужності залежно від частоти стимуляції зміщується в область нижчих частот зі збільшенням маси навантаження. Тому слід обирати навантаження на палець 20 і 40 г, що забезпечить максимальну працездатність пальців.

Розглянуто взаємодію структур, що керують рухом м'язів, скорочення яких викликає згинання пальців руки людини. Досліди показали, що механічне навантажен- 
ня однієї кінцівки спричиняло зниження амплітуди механограми пальців іншої кінцівки (рис. $2 a$ ). При збільшенні інтенсивності контрлатерального навантаження під час стискання груші від одного до трьох разів на секунду незалежно від частоти стимуляції спостерігалося зменшення амплітуди механограми на 29 \% відносно амплітуди механограми без контрлатерального навантаження.

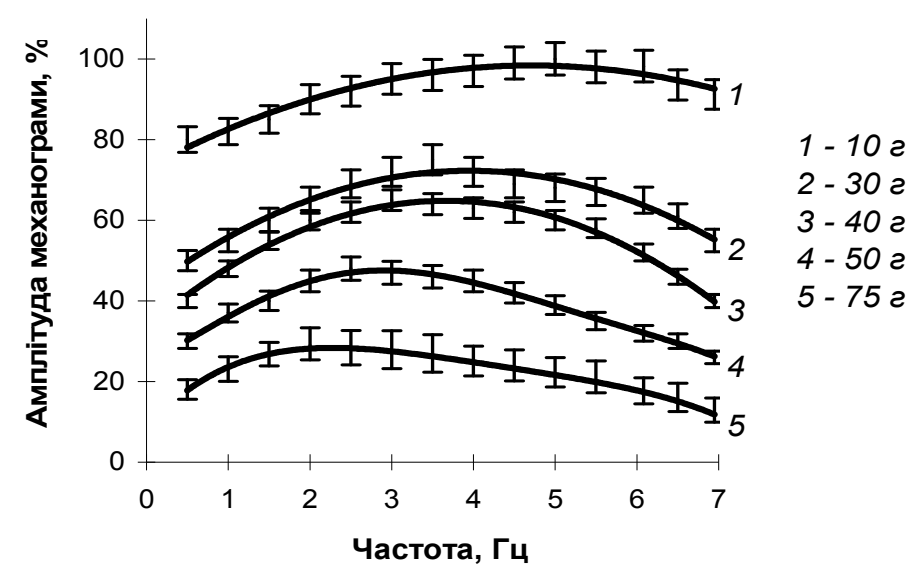

Рис. 1. Залежність відносної амплітуди механограми середнього пальця від частоти стимуляції (усереднені результати 26 дослідів)

Робота, виконувана при стисканні груші, суттєво важча за ту, яка має місце при згинанні одного з досліджуваних пальців, тому регуляція з боку ЦНС може бути спрямована на полегшення виконання важчого фізичного навантаження (стискання груші) за рахунок нервово-м'язової структури, яка виконує легше фізичне навантаження (згинання пальця). Така регулювальна взаємодія, імовірно, відбувається на рівні рухових зон, що координують функції правої та лівої кінцівок.

Зниження м'язової працездатності однієї кінцівки при одночасному виконанні роботи іншою кінцівкою може бути зумовлене також впливом регуляторних механізмів, які корегують надходження енергії (шляхом зміни кровопостачання) в ті чи інші працюючі органи. При цьому суттєву роль відіграє величина навантаження, тому можна зробити висновок про важливу роль реципрокності (спряженості процесів) іннервації, яка характерна для багатьох процесів у високоорганізованих системах.

У наступній серії експериментів досліджувалася ефективність скорочення, викликаного ритмічною стимуляцією м'язів окремих пальців руки, при зміні кровопостачання. Перед реєстрацією механограм стискали плечову артерію манжетою тонометра 3 тиском повітря до 180 мм рт. ст. протягом 3 або 5 хв. Досліди показали, що при однакових частотах стимуляції та різній тривалості стискання плечової артерії амплітуда механограми різна: чим більший час стискання артерії, тим менша амплітуда (рис. 2б). При перетисканні артерії на 5 хв амплітуда механограми менша на $21 \%$ порівняно 3 амплітудою при перетисканні на 3 хв. Отже, простежується чітка залежність відповіді від ступеня зниження надходження крові до досліджуваного м'яза. При цьому відповідно знижується потужність і зменшується діапазон частот реакції відповіді, тобто зменшується м'язова активність. Таке явище можна пояснити тим, що при зменшенні кровопостачання м'язів знижується рівень припливу кисню та поживних речовин, а це викликає швидке стомлення працюючого м'яза. 

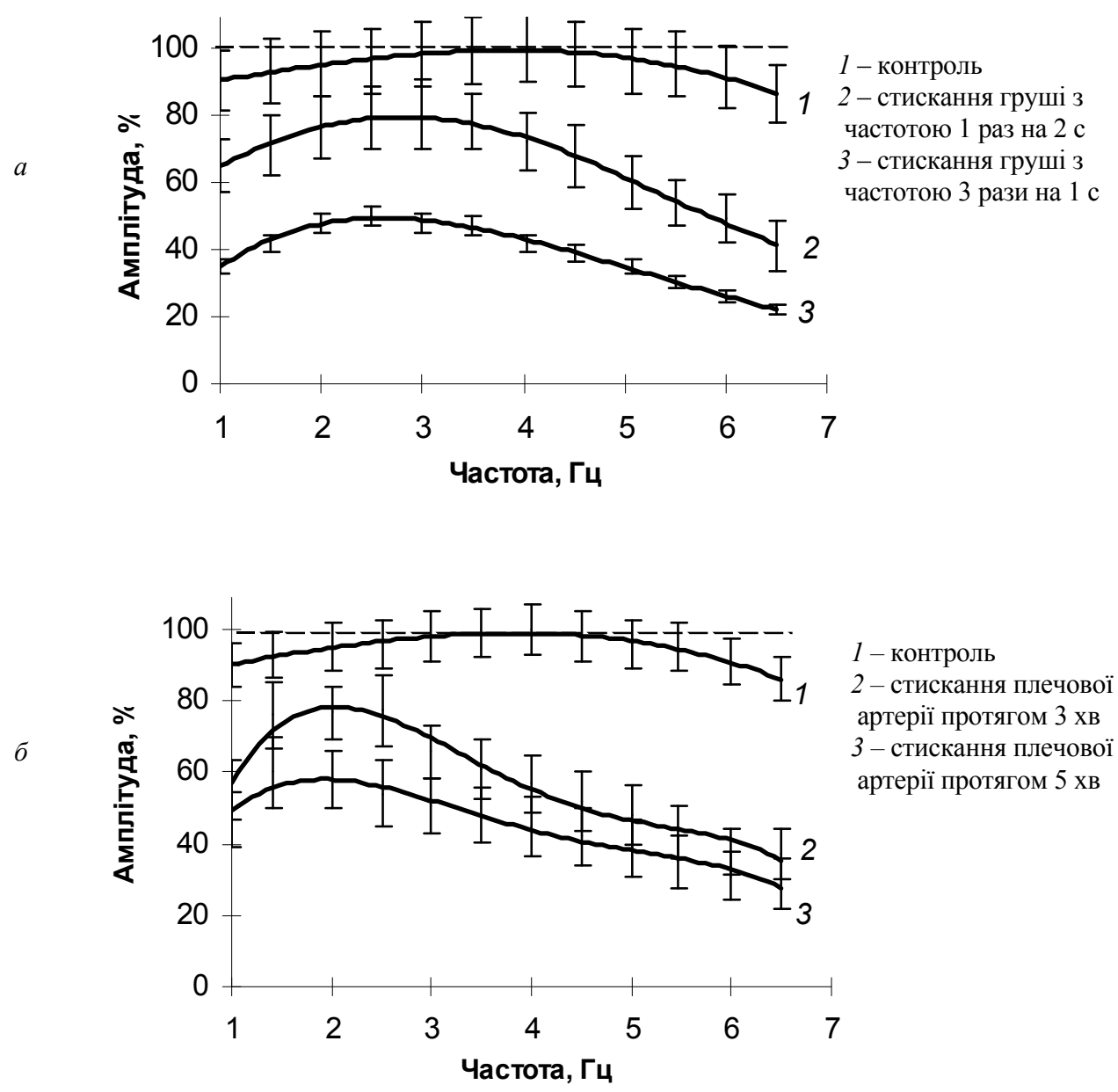

Рис. 2. Залежність амплітуди механограми середнього пальця від частоти стимуляції: $a$ - при контрлатеральному навантаженні; $\sigma$ - при порушенні кровообігу

Під дією різних факторів зниження силових і швидкісних характеристик проявляється різною мірою. Фізична втома більшою мірою знижує властивості м'язів виконувати швидкі рухи та меншою мірою - силові властивості м'язів, втома залежить від частоти та тривалості стимуляції [22]. Відомо [19], що однією з причин утоми є зміни насамперед у самій м'язовій клітині, хоча остаточно не встановлено, який процес або структура відіграють головну роль. Контрлатеральне навантаження, навпаки, знижує силові характеристики більше, ніж швидкісні. Порушення кровообігу та втома знижують як силові, так і швидкісні характеристики м'язів. Таке явище можна пояснити тим, що при зменшенні кровопостачання м'язів знижується рівень припливу кисню та поживних речовин.

\section{Висновки}

При дослідженні динамічних характеристик згинання пальців руки метод функціональної поверхневої механографії мінімізує вплив із боку ЦНС за умови використання подразнення субмаксимальної сили тривалістю подразнювального імпульсу 
не менше 4 мс при навантаженні на палець 20-40 г. Одночасно забезпечується максимум середньої потужності, що розвивається м'язовою системою пальців.

Частотно-динамічні характеристики згинання пальців руки людини змінюються під впливом втоми, порушення кровопостачання та роботи м'язів-згиначів пальців контрлатеральної кінцівки.

Механічне навантаження однієї кінцівки викликає зниження амплітуди механограми пальця іншої кінцівки, яке найменше поблизу частоти, що відповідає максимуму суглобного кута згинання проксимального міжфалангового суглоба, та пропорційне інтенсивності роботи контрлатеральної кінцівки.

Втома м'язів-згиначів пальця та зміна кровопостачання цих м'язів під пневматичним впливом при накладанні манжети на плечову артерію спричинюють зміщення частоти, яка відповідає максимуму суглобного кута, у бік низьких частот.

\section{Бібліографічні посилання}

1. Адаптационные возможности системы иммунитета человека в условиях силовых тренировок / М. П. Рыкова, Е. Н. Антропова, О. Л. Виноградова и др. // Физиология человека. - 2007. T. 33, № 1. - C. 101-108.

2. Бикмуллина P. Х. Тормозные системы спинного мозга в контроле взаимодействий функционально сопряженных мышщ / Р. Х. Бикмуллина, А. Н. Розенталь, И. Н. Плещинский // Физиология человека. - 2007. - Т. 33, № 1. - С. 119-130.

3. Костюков А. И. Динамические свойства двигательной системы млекопитающих. - К. : ФАДА ЛТД, 2007. - 199 с.

4. Литвинюк Л. В. Гистерезистные эффекты сокращения изолированного мышечного волокна при модулированной стимуляции в изометрическом режиме / Л. В. Литвинюк, Д. Н. Ноздренко, Н. С. Мирошниченко // Физика живого. - 2007. - Т. 15, № 2. - С. 84-88.

5. Максакова О. А. Кинетографический метод оценки функционального состояния здорового человека (пилотное исследование) / О. А. Максакова, В. А. Лукьянов // Физиология человека. - 2008. - Т. 34, № 2. - С. $34-43$.

6. Мірошниченко М. С. Нелінійні властивості камбаловидного м'яза щура / М. С. Мірошниченко, Д. М. Ноздренко // Фізика живого. - 2007. - Т. 15, № 1. - С. 50-56.

7. Міщенко В. С. Типи фізіологічної реактивності системи дихання та особливості прояву фізичної працездатності спортсменів / В. С. Міщенко, О. М. Лисенко, В. Є. Виноградов // Фізіол. журн. - 2006. - Т. 52, № 4. - С. 69-77.

8. Ноздренко Д. Н. Реакции нейронов сенсомоторной коры кошки при выполнении сгибательных движений локтевого сустава при постоянной внешней нагрузке // Физика живого. 2008. - T. 16, № 6. - C. 166-170.

9. Петрушанская К. А. Закономерности изменения электромиографического профиля мышщ при некоторых нарушениях ходьбы / К. А. Петрушанская, А. С. Витензон // Физиология человека. -2006 . - Т. 32, № 6. - С. 52-60.

10. Плещинский И. Н. Изменение рефлекторной возбудимости спинального центра камбаловидной мышщы человека при выполнении различных двигательных задач / И. Н. Плещинский, Р. Х. Бикмуллина, А. Н. Розеннталь // Физиология человека. - 2006. - Т. 32, № 2. - С. 31-35.

11. Поварещенкова Ю. А. Модуляция пресинаптического торможения $\alpha$-мотонейронов спинного мозга при механической стимуляции разной направленности / Ю. А. Поварещенкова, Д. А. Петров // Физиология человека. - 2008. - Т. 34, № 1. - С. 108-113.

12. Сонькин В. Д. Физическая работоспособность и энергообеспечение мышечной функции в постнатальном онтогенезе человека // Физиология человека. - 2007. - Т. 33, № 3. - С. 81-99.

13. Тихомирова С. В. Состояние плазменно-коагуляционного гемостаза у физически активных лиц в процессе адаптации к мышечным нагрузкам / С. В. Тихомирова, А. Д. Викулов, А. А. Баранов и др. // Физиология человека. - 2007. - Т. 33, № 6. - С. 88-93. 
14. Шугуров О. А. Исследование мышечной активности при утомлении / О. А. Шугуров, С. Г. Ефанова, Н. П. Власова // Актуальные проблемы современной биологии и медицины. Д. : ДГУ, 1997. - С. 103-105.

15. Шугуров О. О. Мощность разрядов нейронов N1-компонента ПДП спинного мозга при частотной стимуляции кожных нервов // Вісник Дніпропетр. ун-ту. Біологія. Екологія. - 2004. Вип. 12, т. 1. - С. 205-213.

16. Шугуров О. А. Вызванные потенциалы спинного мозга / О. А. Шугуров, О. О. Шугуров. Д. : Наука і освіта, 2006. - 319 с.

17. Щурова Е. Н. Влияние хронической недостаточности периферического кровообращения на функциональное состояние мышц нижних конечностей / Е. Н. Щурова, Л. А. Гребенюк // Физиология человека. - 2002. - Т. 28, № 5. - С. 59-64.

18. Boerio D. Central and peripheral fatigue after electrostimulation-induced resistance exercise / D. Boerio, M. Jubeau, R. Zory et al. // Med Sci Sports Exerc. - 2005. - Vol. 37. - P. 973-978.

19. Fitts R. H. Cellular mechanisms of muscle fatigue // Physiol. Rev. - 1994. - Vol. 74, N 1. - P. 49-94.

20. Gandevia S. C. Spinal and supraspinal factors in human muscle fatigue // Phys. Rev. - 2001. Vol. 81, N 4. - P. 1725-1789.

21. McConnell A. K. The influence of inspiratory muscle work history and specific inspiratory muscle training upon human limb muscle fatigue / A. K. McConnell, M. Lomax // J. Physiol. - 2006. Vol. 577, N 1. - P. 445-457.

22. Wali F. A. Diaphragmatic fatigue in the rat / F. A. Wali, A. H. Suer, C. H. Dark // Acta Physiol. Hung. - 1990. - Vol. 76, N 4. - P. 333-340.

Надійшла до редколегї̈ 26.01.2012 